\title{
Strategy of Planning and Managing Organizational Change in School: School Reform in Croatia
}

\author{
Marija Valcic ${ }^{1}$, Jadranka Herceg ${ }^{2}$ \\ ${ }^{1}$ University of Applied Science Baltazar, V. Novaka 23 \\ 10290 Zaprešic, Croatia \\ marija.valcic@bak.hr \\ ${ }^{2}$ Agency for Vocational Education and Training and Adult Education \\ Zagreb, Radnickacesta \\ jadranka.herceg@asoo.hr
}

\begin{abstract}
The last two decades of 20th century and the first decade of 21st century witnessed a remarkable quickening and expansion of efforts to reform Croatian schools. It is almost certain in schools well into the 21st century. The term school reform often means very different things to different people because they use various theories in trying to understand and explain issues such as education, schools as organizations, and human behavior. The school reform generally connotes planned efforts by those external to the school to cause changes, or restructuring, to occur within the school (Empirical rational strategies; Power-coercive strategies; Organizational self-renewal strategies).
\end{abstract}

Keywords: Digital Education, Croatia Schools

Received: 26 September 2018, Revised 12 December 2018, Accepted 22 December 2018

DOI: $10.6025 / \mathrm{jdp} / 2019 / 9 / 2 / 51-55$

(C) 2019 DLINE. All Rights Reserved

\section{Introduction}

\section{Is School Reform Enough?}

What does it mean to transform the school? What does it mean for Croatian government or Labor market? The process of reinventing begins within the leader who creates, within him-or herself, a new vision of what the school should become in the near future and beyond. It could start by reconsidering a core set of values and beliefs that redefine the culture of the school. We are talking about the ways in which the professional practice cloistered in their individual classrooms to teaching practice that is a collegial, collaborative professional enterprise [1].

All that we know about schools as organizations and the behavior of people in them is brought into play when we confront the need to plan and manage change, or reform, in them. In fact, the fundamental issue is planning and managing change in a school, in which the leader finds powerful leverage points for triggering planned and managed organizational change [2]. Critics of 
Croatian schooling have a propensity to depict schools as static bureaucracies, stodgy, lumbering about, and unable to adapt to emerging demands for high performance.

In Croatia, education system today begins in preschool institutions, which include those run by local authorities and private nursery schools (legal persons, religious communities, and others), and institutions which provide preschool programmes and shorter programmes such as libraries, various associations and elementary schools. Nurseries are responsible for full-day or shorter programmes of education, health care, nutrition and social care, which cover children from the age of six months to when they start school. In 2014, 40\% of pre-school aged children attended them, while over $99 \%$ attend in the year before they start school. Children who are six and a half or over must attend compulsory elementary education, which lasts 8 years. There is an adult education system for those over the age of 15 who fail to complete elementary education. Upon completing their elementary education, children may continue optional secondary education which is divided according to curricula into gymnasiums, vocational schools (technical, industrial and craft based) or art schools (music, dance, art). Gymnasiums provide a comprehensive syllabus which lasts 4 years and includes a final examination, the state matura. Programmes in vocational and art schools last from one to five years, and usually end with the production of a final assignment, but it is also possible to sit the state matura if pupils have completed four years of secondary education. Since 2010, state matura results have been the basis for entry to higher education institutions. Along with secondary education, there are also programmes which prepare people to work in their chosen vocations and adult education programmes. Elementary and secondary education in state schools is free.

Higher education is conducted in higher education institutions through university and professional studies. Higher education institutions are divided into polytechnics, colleges of applied science, faculties and art academies. All courses were aligned by 2005 with the requirements of the Bologna Process as a part of the creation of a European system of higher education [5].

University studies equip students for work in science and higher education, in the business world, public sector and society. University studies are organised and implemented at universities which comprise several faculties, and may be at the level of undergraduate, graduate or postgraduate studies. After completing a three or four-year undergraduate course, students are awarded the title of Bachelor (univ.bacc.) and after a further one or two years of graduate studies, the title of Master (mag.). Postgraduate studies last three years and end with the defence of a doctoral dissertation, after which the academic title of Doctor of Science (dr. sc.) or Doctor of Arts (dr. art.) is awarded.

Professional studies provide students with the knowledge and skills they will require to work in professional occupations. Professional studies, which last two to three years, are conducted in colleges of applied science or polytechnics and may also be conducted in universities. Upon completion, graduates are awarded the title of Professional Bachelor (bacc.) with reference to a specialisation. Polytechnics and colleges of applied science may organise specialist graduate professional studies lasting one or two years for students who have completed professional study courses or undergraduate university courses, and these studies lead to the academic title of Professional Specialist (stru. spec.) with reference to a specialisation. Universities may organise postgraduate specialist studies which last one or two years, which lead to the academic title University Specialist (univ. spec.) with reference to a specialization [6].

The university has a long tradition in Croatia. The first university was established in Zadar in 1396, a century before the Dominican order promoted the level of courses to studia generalia with all university rights and privilèges in 1495 . The beginnings of Zagreb University date back to 1669, when King Leopold promoted the Zagreb Jesuit Academy to the level of a university. The Decree of the Empress Maria Theresa of 1776 ordered the establishment of the Royal Academy of Science, which at first had three faculties: Theology, Law and Philosophy. The modern University of Zagreb was founded in 1874 and its component faculties were Theology, Law, and Philosophy. Today, it is the largest university in the country and comprises 29 faculties, 3 academies and university centres. There are also universities in Dubrovnik, Pula, Rijeka, Osijek, Split and Zadar, and a Catholic University in Zagreb.

Today, 90 public and 42 private higher education institutions are operating in Croatia. The largest number of students, $67.5 \%$,are enrolled in university courses in faculties.

Croatian curricula framework is following its adoption by the Croatian parliament on February 8, 2013, the CROQF Act came into force on March 2, 2013.

Croatia is still a country in transition, fortunately with a long tradition in European education, but unfortunately with great 
problems in the sustainability of the education system to labor market needs.

\section{Tree Strategies of Planned Change}

Tree major strategic orientations are useful in planning and managing organizational change:

1. Empirical-rational strategies.

2. Power-coercive strategies.

3. Normative-reducative strategies.

Traditional, process of unplanned dissemination of new ideas to schools have given way to strategies of planned, managed dissemination intended to spread new ideas and practices swiftly. Much research and study have been devoted to these strategies, which focus primarily on more closely linking the findings of research to the practices of education. This approach sees the scientific production of new knowledge and its use in daily activities as the key to planned change in education. It is referred to broadly as knowledge production and utilization (KPU).

Various models for implementing KPU concept of change appear under different appellations, depending on the number of steps that are seen as important. An R and D model, for example, suggests that someone ought to be conducting research and that someone else ought to be developing some useful products from that research. As in KPU models, research is meant here to be the innovation or discovery of new knowledge, regardless of its applicability to immediate problems. In R and D work, the quality and validity of the research are of paramount importance. The development phase of $\mathrm{R}$ and $\mathrm{D}$ includes factors such as solving design problems, considering feasibility in real world conditions and cost. Development essentially means translating research into products that are practical for use; these can range from school buildings to pupil seating, from textbooks to comprehensive packaged curricula. In free enterprise societies, this stage has largely been the province of profit seeking firms that have the necessary financial resources and entrepreneurial skills [3]. The diffusion phase of R, D, and D is seen as the third and distinctive phase; it is, essentially, the marketing activities of $\mathrm{R}, \mathrm{D}$, and $\mathrm{D}$. The aim is to make the new products readily available in an attractive, easy-to-use form at a reasonable cost to the adopter.

Of course, the ultimate goal is to get the new into use. Therefore, some treat adoption as a separate aspect of the process and may even call it research, development, dissemination and adoption (R.D.D.A.) to emphasize this point.

We are used the term innovation in referring to planned specific change that is intended to help organization a) achieve existing goals more effectively or b) achieve new goals. The concept of specificity is crucial: "innovations in educations ordinarily have a defined, particular, specified character" [7]. Usually one speaks of an innovation as something that can be specified in terms of concept, a set of operating procedures, and a relevant technology to which we attach a name, for example, magnet schools, alternative education, reading program.

Power-Coercive Strategies of Change and empirical-rational strategies of change share two assumptions: that good ideas are best developed outside the organization and that the organization is the target of external forces for change. Power-Coercive Strategies are based on the, or potential use, of sanctions to compel the organization to change. All acts of our Ministry of Science, Education and Sports is a compendium of power-coercive strategies complete with required timetables for action, requirements for reporting compliance, and various sanctions and rewards intended to coerce the schools to comply with the demands for prescribed improvement in performance on standardized tests. Many authors started (see [2]) by pointing out that the conventional model for studying educational change is to manipulate certain instructional interventions and look for changes in student or pupil outcomes. This suggested the need to focus on the entire culture of the school, operational curriculum, written and unwritten rules, verbal and nonverbal communication, physical properties, pedagogical regularities, principal's, leadership behavior and so on [4].

Normative-reeducative strategies are based on the school organizations improving their problem solving capabilities. This requires shifting the normative values of the school's culture (interaction influence system, from those usually associated with hierarchical (bureaucratic, mechanistic, classical) organization to more creative, problem solving norms. classical) organization to more creative, problem solving norms. 
Techniques and processes for bringing about organizational self- renewal focus on developing and increasing the skills of the staff members of individual schools in studying and diagnosing their own organizational problems systematically and in working out solutions is widely applied to these techniques for increasing the self-renewal capacity of schools.

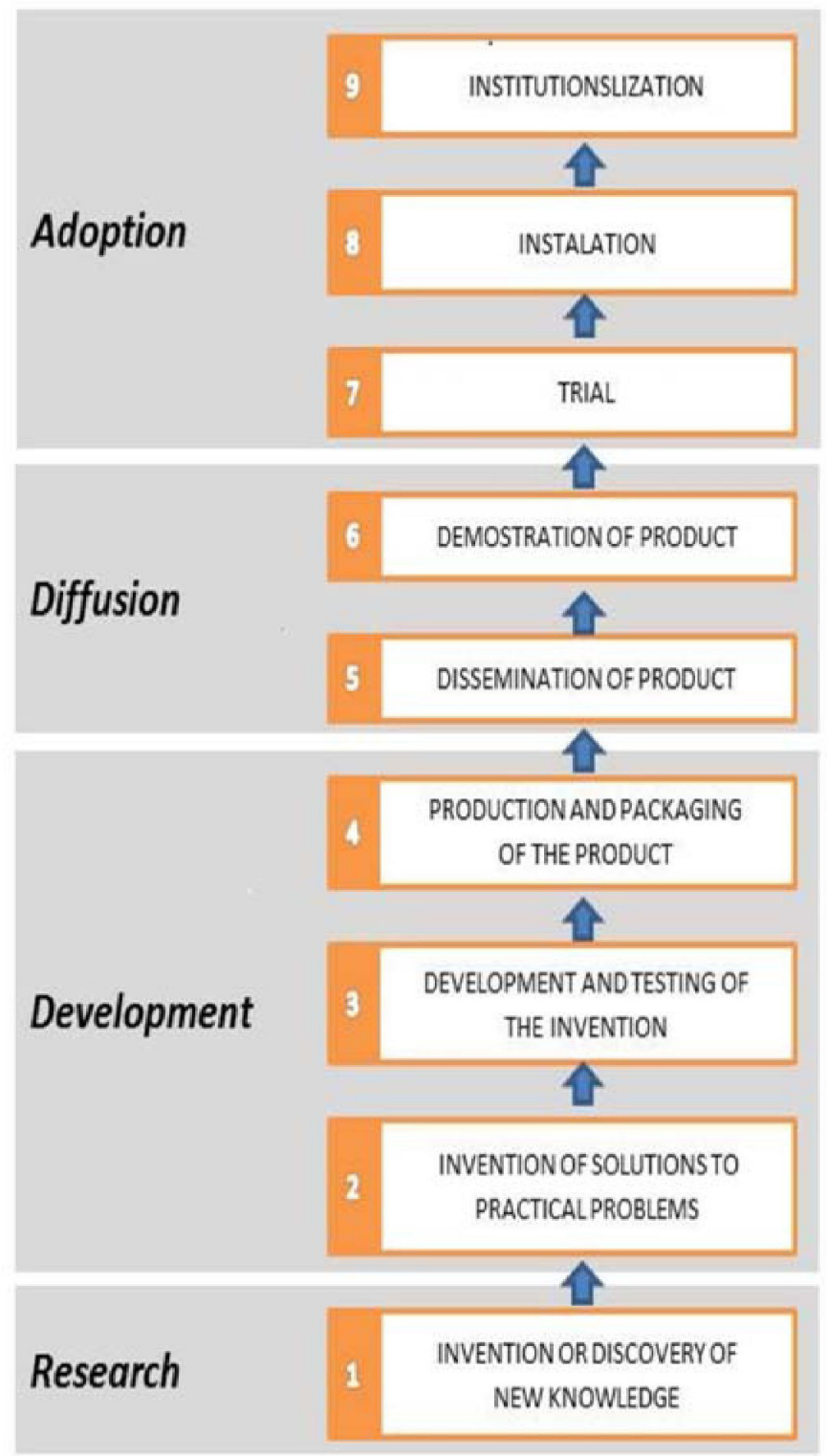

Figure 1. Concept of the research, development, diffusion, and adoption (R.D.D.A.): model of change

\section{Conclusion}

Schools are organizationally different from many other kinds of organizations, such as those in business, the military, and the nonprofit field. They possess special properties (not all necessarily unique) that may well affect the ways in which they should deal with issues of stability and change. For example, they are largely populated by a student body completed to attend. Six other special properties must be considered in planning change.

The critical importance of helping schools to develop their own capacity for self-renewal was not widely understood outside the field of organizational behavior until the failure of extensive applications of both empirical-rational and power-coercive strategies to achieve desired levels of success had produced widespread frustration and concern. By improving the organizational health 


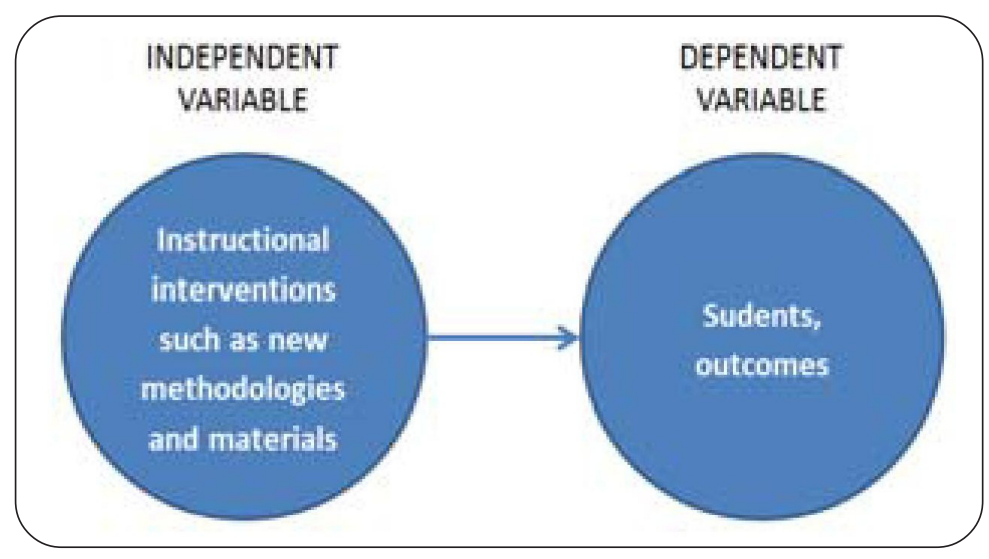

Figure 2. Conventional model

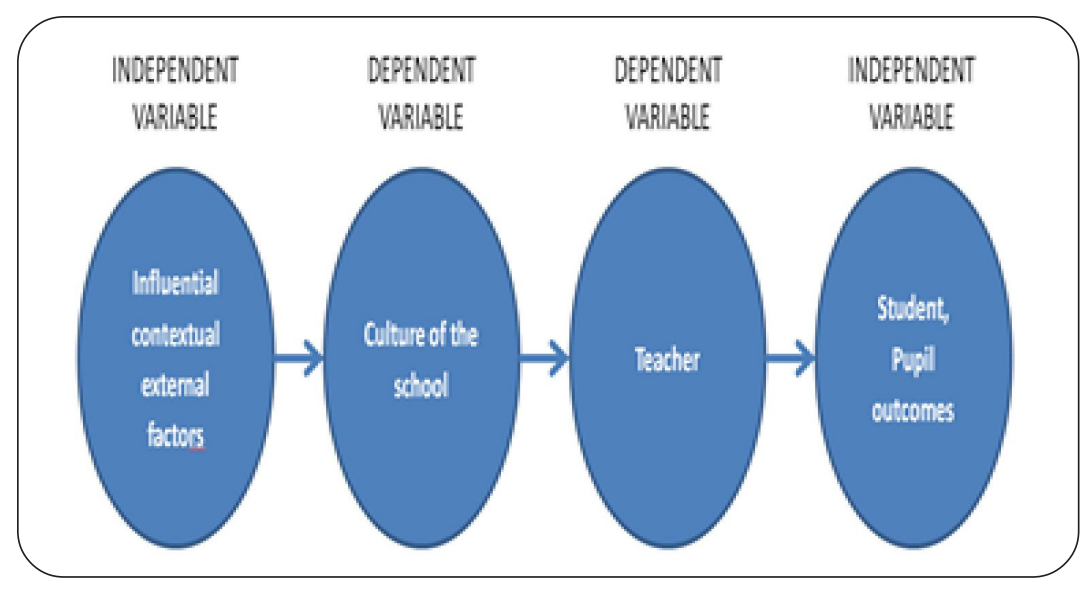

Figure 3. A paradigm for improving and studying educational practice with changes in the entire culture of a school

of schools, it is possible to make schools more proactive than defensive and induce them to reach out responsively to adopt new ideas and implement the changing goals of society.

\section{References}

[1] Communication from the commission to the European Parliament, the Concil, the European Central Bank, Brussels, 28.11.2014 $\operatorname{COM}(2014) 902$ final. 2014.

[2] Goodlad, J. (1975). The Dynamics of Educational Change. NY, McGraw-Hill Book Company. 1975.

[3] Lisbon Strategy evaluation document. Brussels (2010). 2.2.2010 SEC (2010) 114 final 2010.

[4] OECD. (2007). Thematic Review of tertiary education country background report for Croatia. Ministry of Science, Education and Sports RC. 2007.

[5] Polazne osnove za mre•u visokih ucilišta i studijskih programa u RH. Agencija za znanost i visoko obrazovanje, 8.srpnja 2010. 2010.

[6] Zakon o hrvatskom kvalifikacijskom okviru, Ministarstvo znanosti, obrazovanja i sporta, Zagreb, NN: 22/2013. 2013.

[7] Miles. M. B. (1964). Innovation in Education. 